\title{
PERAN PUBLIC RELATIONS DALAM MEMPENGARUHI KONTEN MEDIA
}

\author{
Rizki Hidayat \\ Mahasiswa Magister Ilmu Komunikasi Angkatan VII \\ rizkymorteza@gmail.com
}

\begin{abstract}
In this era of globalization of business competition is getting higher. Especially in economic sectors where big companies from abroad increasingly free to operate and market its products in Indonesia so that local companies can not compete with itself would be eliminated. The purpose of this study was look at the effectiveness of IT utilization is also the creativity of a public relations. Popularity of media and social networks such as Facebook, Twitter, YouTube, spur the growth of "medium alone" that allows companies and organizations to set up reporting directly or through intermediaries and remediation (where, the media took the headlines of social media and republish). The results of this study indicate that the majority of social media is 'parasitic', take a lot of information and topics of the mass media. Public relations in general is a process of communication management activities to create mutual understanding between an organization and its publics.
\end{abstract}

Keyword : public relations, media ethics, media content

\section{Pendahuluan}

Media berfungsi sebagai sarana penyebarluasan informasi tentang perusahaan kepada khalayak. Public relations harus memandang media sebagai mitra kerja yang saling mendukung, media adalah patner kerja public relations. Public relations secara umum merupakan proses aktivitas manajemen komunikasi untuk menciptakan mutual understanding antara organisasi dan publiknya. Agar tujuan itu dapat dicapai, prinsip kesetaraan dan kesederajatan dalam setiap program komunikasi menjalin relasi publik merupakan pijakan awal. Menurut Kent \& Taylor (2002: 28) bahwa kesetaraan ini terwujud pada rasa empati 'walking in the same shoes' dan mutualitas (semangat kesejajaran \& berkolaborasi). Merupakan landasan awal proses public relations mencapai kondisi mutual understanding dalam peranannya terhadap konten media. Di sisi lain, tugas public relations juga untuk mempromosikan nilai-nilai multikultural dalam masyarakat.

Public relations bertanggung jawab menyampaikan dan menerima informasi dari 90 khalayak sedangkan media bertanggung jawab menjalankan hak publik untuk memperoleh informasi. Adapaun peran PR dalam media penyiaran, yakni: (1) sebagai organisasi, media memiliki lembaga public relations yang membutuhkan prinsip sebagai landasan fungsionalnya; (2) tayangan media penyiaran seharusnya menjadi alat public relations media tersebut untuk mensosialisasikan prinsipnya; (3) dalam konteks lebih luas, penyiaran adalah alat mengedukasi sekaligus menjadikan public relations sebagai nilai-nilai yang berbangsa, secara umum dalam konteks global.

Mengacu pada UU Pokok Pers No 40/1999 dan UU Penyiaran No 32/2002 sudah menstimuli sosialisasi multikultural. Dalam UU Pokok Pers No 40/1999: pasal 5: “... memberitakan peristiwa dan opini dengan menghormati norma agama dan rasa kesusilaan masyarakat; Pasal 6: "menegakkan nilai dasar demokrasi, mendorong supremasi hukum dan HAM serta menghormati kebhinekaan. Sementara UU Penyiaran No 32/2002: Pasal 2: "Penyiaran diselenggarakan berdasarkan Pancasila dan Undang-Undang Dasar Negara 
Republik Indonesia Tahun 1945 dengan asas manfaat, adil dan merata, kepastian hukum, keamanan, keberagaman, kemitraan, etika, kemandirian, kebebasan, dan tanggung jawab; Pasal 3: Penyiaran diselenggarakan dengan tujuan untuk memperkukuh integrasi nasional, terbinanya watak dan jati diri bangsa yang beriman dan bertakwa, mencerdaskan kehidupan bangsa, memajukan kesejahteraan umum, dalam rangka membangun masyarakat yang mandiri, demokratis, adil dan sejahtera, serta menumbuhkan industri penyiaran Indonesia; Pasal 36 tentang isi siaran, antara lain: Isi siaran wajib dijaga netralitasnya dan tidak boleh mengutamakan kepentingan golongan tertentu, Isi siaran dilarang bersifat fitnah, menghasut, menyesatkan dan/atau bohong; menonjolkan unsur kekerasan, cabul, perjudian, penyalah-gunaan narkotika dan obat terlarang; atau mempertentangkan suku, agama, ras, dan antargolongan; dilarang memperolokkan, merendahkan, melecehkandan/ataumengabaikan nilai-nilai agama, martabat manusia Indonesia, atau merusak hubungan internasional.

\section{Pembahasan}

\section{- Perspektif Public Relations dalam Media Multikulturalisme}

Media sangat berperan dalam mendorong terbentuknya masyarakat multikultural. Media berperan sebagai ruang publik ke masyarakat. Media massa mempunyai kemampuan diseminasi informasi secara serentak, repetisi, dan simultan yang membuat media mempunyai kekuatan dalam membentuk opini. Di tengah perkembangan teknologi komunikasi, pesanpesan media menjadi "virus" yang menjadi menu sarapan di pagi hari dan pengantar tidur di malam hari. Meminjam istilah Elizabeth Noelle Neuman, fenomena ini dikenal dengan 'ubiquity', individu tidak dapat lari dari terpaan media karena gencar dan berulang-ulangnya terpaan media hadir di kehidupan sehari-hari. Informasi-informasi yang disampaikan pun terakumulasi dan mempunyai efek luar biasa dalam transfer pengetahuan.
Pengetahuan yang merupakan realitas subjektifhasil konstruksimedia ini pada akhirnya mampu "menggoyang" persepsi publik terhadap realitas objektif. Publik pun menganggapnya sebagai sebuah kebenaran yang tersimpan dalam realitas subjektifnya. Realitas baru hasil konstruksi media inilah yang sering menjadi istilah dari Walter Lippman 'the picture in the head'-nya publik. Dibanding media lain, televisi sebagai media penyiaran memiliki power untuk membentuk opini dan cara pandang 'worldview' masyarakat karena sifatnya yang audio visual dan mudah dinikmati. Pamela J. Shoemaker dan Stephen D. Reese (1996 : 11), dalam Mediating The Message: Theories of Influences on Mass Media Content, menyusun berbagai faktor yang mempengaruhi pengambilan keputusan dalam ruang pemberitaan.

Adapun faktor-faktor public relations dalam media massa menjadi agen penyebar multikulturalisme, yakni :

1. Membangun kesadaran kepada pekerja media dan konten media.

a. Lebih menonjolkan budaya mayoritas

b. Terjerumus pada pelabelan negatif dalam hal ini semakin maraknya 'jurnalisme kuning' disetiap konten media

c. Melakukan fragmentasi atau isolasi peran pada kelompok tertentu,

d. Mengumbar kelemahan atau kekurangan fisik, seperti obesitas, penyandang difabel atau disabilitas

2. Menjauhkan isi media yang masih mengandung distorsi.

a. Distorsi masyarakat, yaitu ketika aksi-aksi masyarakat mengancam kebebasan media, seperti aksi anarkis menyerbu kantorkantor surat kabar karena tidak setuju dengan pemberitaan media tersebut.

b. Distorsi pekerja media, yaitu ketika pekerja media tidak dapat menjaga profesionalitasnya dalam menulis berita, sehingga menghasilkan distorsi informasi.

3. Tayangan dalam hak bermedia dari publik Hak akan informasi publik, hak untuk membedakan tiga komponen isi penyiaran (berita, opini, dan niaga), serta hak kesetaraan dalam kemajemukan. Distorsi 
informasi (menambah atau mengurangi informasi), dramatisasi fakta palsu (bertujuan membangun suatu citra negatif dan sterotipe), mengganggu "privacy" (praktik ini banyak dilakukan dalam kehidupan selebritis dan kaum elit, utamanya yang diduga terlibat dalam suatu skandal), pembunuhan karakter (meskipun sebenarnya masih banyak sisi baik dari narasumber, namun yang digambarkan sisi buruknya), eksploitasi seks (hanya menjual popularitas dan bombastis), meracuni anak-anak, penyalahgunaan kekuasaan/ abuse of power (pihak redaksional, melalui interpretasi dan ilustrasi faktual subyektif, dapat mengidentifikasikan suatu persoalan sesuai kepentingannya).

4. Sosialisasi literasi media pada masyarakat

Disebut juga melek media, yaitu keterampilan untuk menganalisis isi media. Dalam tataran yang sederhana, melek media adalah keterampilan untuk mencerna tayangan media, mengkritisi, dan memilih untuk tidak mengonsumsi tayangan karena menyadari isi tayangan tersebut memunculkan resiko. Tujuannya agar konsumen media lebih mampu memahami dan tidak mudah meniru adegan yang terdapat dalam tayangan apabila hal tersebut berbahaya (Kriyantono, 2007 : 56).

Menurut Kriyantono (2012: 60) sifat multikultural adalah sifat yang mengakui dan menghargai perbedaan dalam kesederajatan, sifat ini tumbuh dari paham multikulturalisme, yaitu cara pandang tentang keberagaman kehidupan yang menekankan penerimaan terhadap realitas perbedaan agama, budaya, dan worldview yang terdapat dalam masyarakat. Jika sifat multikultural ini terinternalisasi pada diri individu, maka individu tersebut akan secara terbuka memahami, menghargai serta mengkaji budaya orang lain yang dilandasi oleh semangat menghormati dalam kebersamaan. Dalam konteks negara-bangsa, multikulturalisme ini mencakup upaya-upaya menghargai kesetaraan dari pluralitas budaya di masyarakat, kesetaraan dalam perumusan kebijakan untuk penanganan perbedaan budaya, etnis, dan agama, penghargaan akan kesetaraan gender, penegakan hukum, kesempatan pendidikan, berusaha, HAM, hak budaya komunitas dan minoritas.

\section{- Public Relations dalam Objektivitas Pemberitaan}

Media juga mesti mempunyai kesadaran untuk melakukan tugas jurnalistik dengan mengedepankan prinsip pemenuhan akan informasi publik, yang akan mendorong sifat kritis dan objektif beriringan dalam berita yang dibuat. Kemampuan menulis berita dengan prinsip objektivitas berita dari Westerthal (dalam McQuail, 2011: 70) yaitu Faktualitas dan Imparsialitas, akan menghindarkan para pekerja media dari praktik jurnalistik yang menyimpang (jurnalisme kuning), produk informasi yang tidak berkualitas.

\section{- Faktualitas}

Berarti bahwa berita harus berdasarkan fakta bukan karangan atau opini wartawan. Fakta dalam berita harus dapat dikonfirmasi ulang atau dicek dengan sumber berita. Tidak mencampuradukkan antara fakta dengan opini pribadi wartawan. Fakta adalah hasil pengamatan dan wawancara si wartawan. Sedangkan opini adalah pendapat yang berisi nilai-nilai pribadi wartawan. Termasuk faktual di sini adalah sifat relevansi dan informatif. Relevansi berarti bahwa media harus mempertimbangkan dampak berita bagi publik. Sementara berita dituntut berisi informasi yang jelas dan lengkap mengenai peristiwa yang diberitakan. Jangan malah membuat si pembaca bingung dan tidak jelas. Agar informatif, berita harus komprehensif dan fokus, ringkas (concise), jelas (clarity), mengandung unsur $5 \mathrm{~W}+1 \mathrm{H}$, dan mudah dipahami.

\section{- Imparsialitas}

Bahwa berita tidak berpihak pada golongan tertentu dan tidak sepotong-sepotong dalam memberitakan peristiwa. Ada dua ciri berita yang imparsial, yaitu:

1. Berita harus seimbang dalam pemberitaannya (balance), yaitu dengan memberikan proporsi yang seimbang antara berbagai pihak yang diberitakan (cover both sides). 
2. Berita harus menceritakan apa sesungguhnya yang terjadi. Jika sumber berita A lebih banyak diberitakan daripada sumber berita B maka berita itu tidak seimbang; Jika pihak A diberi porsi liputan lebih banyak, sedangkan pihak B hanya diberi sedikit, maka berita itu tidak seimbang dan cenderung memihak pada A. Jadi berita harus netral dan tidak sepotongsepotong.

Netral dimaksudkan untuk tidak memihak salah satu pihak dengan memberikan opiniopini pribadi wartawan ditulis berdasarkan konteks peristiwa secara keseluruhan dan tidak dipotong-potong oleh kecenderungan subjektif. Kenetralan ini dapat dilihat dari pilihan kata atau kalimat maupun pilihan sudut pandang (angle) pemberitaan. Kode Etik Jurnalistik, misalnya, disebutkan bahwa wartawan Indonesia selalu menguji informasi, memberitakan secara berimbang dan adil, tidak mencampurkan fakta dan opini yang menghakimi serta menerapkan asas praduga tak bersalah. Dewan Pers sendiri pernahmengadopsi model objektivitas Westerthal ini saat melakukan riset tentang keobjektivan berita yang ditulis surat kabar di Jawa pada tahun 2004. Selain aspek faktualitas dan imparsialitas, ada dua poin penting untuk berita yang objektif, yaitu aspek narasumber kredibel dan aspek nilai berita. Berita yang baik adalah berita yang menampilkan narasumber atau sumber berita yang terjamin kapabilitasnya dalam memberikan kesaksian atau informasi tentang peristiwa yang diberitakannya. Narasumber yang dipilih haruslah yang memiliki keahlian di bidangnya, keterkaitan dengan peristiwa dan bisa dipercaya. Sementara, agar menarik minat khalayak untuk membacanya, maka berita harus mengandung nilai berita (news-values).

\section{- Kredibilitas}

Persoalan akurasi sangat menentukan kredibilitas media di mata publik. Kasus akurasi yang banyak muncul di media saat ini disebabkan antara lain minimnya cek-ricek dan kelalaian (kesengajaan) pencantuman sumber berita. Kelalaian pencantuman sumber berita dapat mengakibatkan berita yang disajikan tidak dapat diverifikasi di lapangan. Namun demikian, tidak semua yang diungkapkan narasumber benar, meskipun ada kredo: it is true that the source said this (menjadi benar apabila ada rujukan siapa yang mengatakan) (Mencher, 2000: 182). Secara mendasar akurasi mengindikasikan perlunya verifikasi terhadap fakta/informasi. Seluruh informasi yang diperoleh harus diverifikasi sebelum disajikan. Dari sejumlah parameter yang digunakan untuk mengukur akurasi, persoalan verifikasi terhadap fakta dan akurasi penyajian menjadi masalah utama di sejumlah media. Verifikasi terhadap fakta menyangkut sejauh mana berita yang ditampilkan berkorespondensi dengan fakta yang benar-benar terjadi di lapangan.

Menyangkut akurasi penyajian, beberapa media memiliki kelemahan umum dalam hal teknik penulisan berita, termasuk di sini kesesuaian judul dengan isi berita, ejaan kata maupun tanda baca (Mencher, 2000: 182). Untuk itu, wartawan yang kemudian dilanjutkan oleh editor, perlu melakukan cek dan cek lagi, koreksi kesalahan tulis, dan meningkatkan kecermatan dalam penggunaan bahasa. Sekali lagi, indikator akurasi yang pokok adalah sumber berita yang jelas dan adanya data-data yang mendukung. Macam-macam kesalahan akurasi antara lain: (1) omission (kelalaian atau tidak mencantumkan sumber); (2) under atau over emphasis (kurang dalam memberi perhatian atau tekanan); (3) misspelling; kesalahan eja; (4) faulty headlines (headlinesalah) atau inkonsistensi antara headline dan isi; (4) misquotes, incorrect age, name, date, and locations: kesalahan mengutip, penulisan umur, nama, tanggal, dan lokasi atau nama tempat (5) kesalahan menampilkan atribusi narasumber. Akurasi atribusi narasumber dilihat dari kesesuaian person/organisasi; siapa dia; apa keahliannya; dan sebagainya).

Reporter harus mengidentifikasi ulang sumber-sumber informasi sebelum menyajikan berita, terkait akurasi sumber informasi. Idealnya penyebutkan sumber harus menyebutkan nama, bukan anonim (tanpa nama). Menurut Mencher (2000: 8), ada 4 tipe atribusi (penyebutan sandangan nama) yaitu 
(a) on the records: seluruh statement dan atribusi dapat dikutip (perlu sebutkan nama dan titel yang memberikan statement); (b) on background: seluruh statement dapat dikutip tapi tidak untuk atribusi (narasumber tidak dapat disebutkan secara detil hanya disebutkan misalnya: "A White House official"); (c) on deep background: apapun yang dikatakan oleh sumber tidak dapat dikutip langsung, begitu pula identitas narasumber sehingga jurnalis menulis sendiri kisah tersebut; (d) off the record: informasi hanya untuk pengetahuan reporter saja dan tidak dapat disebarluaskan. Informasi pun tidak dapat digunakan untuk mendapatkan konfirmasi dari narasumber yang lain.

Sementara itu, Deborah Howel (dalam Kovach dan Rosenstiel, 2004), menyebutkan aturan (baca: larangan) dalam penggunaan anonim: (1) jangan pernah menggunakan sumber anonim untuk memberi opini terhadap pembaca; (2) jangan pernah menggunakan sumber anonim sebagai kutipan pertama dalam tulisan. Anonimitas sesungguhnya telah diatur dalam Kode Etik Jurnalistik (KEJ), bahkan menjadi hak wartawan, yang disebut sebagai Hak Tolak. Pada pasal 7 KEJ disebutkan: "Wartawan Indonesia memiliki hak tolak untuk melindungi narasumber yang tidak bersedia diketahui identitas maupun keberadaannya, menghargai ketentuan embargo, informasi latar belakang, dan "off the record" sesuai dengan kesepakatan." Penafsiran dalam KEJ ditulis sebagai berikut: (1) Hak tolak adalak hak untuk tidak mengungkapkan identitas dan keberadaan narasumber demi keamanan narasumber dan keluarganya; (2) Embargo adalah penundaan pemuatan atau penyiaran berita sesuai dengan permintaan narasumber; (3) Informasi latar belakang adalah segala informasi atau data dari narasumber yang disiarkan atau diberitakan tanpa menyebutkan narasumbernya; dan (4) "Off the record" adalah segala informasi atau data dari narasumber yang tidak boleh disiarkan atau diberitakan.

\section{- Analisis Peran Public Relations dalam Mempengaruhi Isi Media}

Public relations memiliki peran penting dalam media korporasi antara pihak organisasi dan pihak publik. Seorang public relations memiliki visi dalam membangun citra baik organisasi agar terhindar dari intervensi dari kalangan publik yang dapat menjatuhkan organisasi yang dijalankan. Dalam membangun suatu kerja sama antar organisasi seorang public relations memiliki strategi masing-masing sebagai jembatan satu sama lain agar kedua pihak dapat menjalin kerja sama yang baik. Hal ini bertujuan untuk menciptakan saling pengertian dan dukungan bagi tercapainya suatu tujuan tertentu demi citra positif bagi organisasi medianya. Public relations merupakan fungsi manajemen untuk mencapai target tertentu yang sebelumnya harus mempunyai program kerja yang jelas dan rinci, mencari fakta, merencanakan, mengkomunikasikan, hingga mengevaluasi hasil-hasil apa yang telah dicapainya.

Media massa dapat mengontrol aliranaliran informasi melalui gatekeepers (penjaga gerbang media). Media berita secara rutin juga melakukanpenambahankaryawan, berlangganan layanan berita dan berjaringan dengan beberapa media lainnya, selain juga mempertahankan pekerja freelancenya dan mungkin kontribusi luar juga datang dari siaran pers. Orang-orang media selalu mengevaluasi siaran persnya untuk mencari standarisasi, kedekatan jarak, ketepatan waktu dan kegunaanya. Karena siapa yang akan diberitakaanya; narasumber dan bentuk fisiknya, agar dapat mempengaruhi penggunaan informasi secara potensial. Dua hal penggunaan siaran pers dalam pertimbangan etis, yakni pengirim dan penerima. Dimana akurasi dan kejujuran diharapkan mampu mengembangkan dan mengangkat masalah etika terkait, seperti : memelintirkan berita atau informasi. Cara lain untuk melibatkan masyarakat dalam memenuhi siaran dan standar kebutuhan yang bervariasi, yaitu adanya motivasi dan nilainilai etika bermedia.(1) Adanya keputusan etis dalam mengevaluasi suatu program media;, (2) Mempertimbangkan materi atau konten yang menjadi standar dalam etika media. Karena 
pada umumnya keputusan etika media yang menyangkut kekerasan dan seksualitas dalam sebuah program media akan menjadi ancaman terhadap kepercayaan.

Gordon menyampaikan bahwa "media massa seharusnya mengabaikan berita dari narasumber yang tidak benar, karena akan menjadi ancaman terhadap manipulasi konten". Di sini peran public relations (PR) perlu ambil bagian, karena sebagai pemelihara hubungan yang sehat dalam lingkungan organisasi. Dan yang mempengaruhi manipulasi konten media biasanya mereka yang memiliki kepentingan. Contohnya informasi yang bersifat mempromosikan sesuatu atau seseorang, produk, calon pemegang jabatan politik dengan tujuan sangat bermanfaat untuk kepentingannya sendiri atau kelompok.Menurut Lasch bahwa "banyak pers dalam menginformasikan kepada masyarakatnya yang setara dengan sampah mall" (misalnya, informasi yang disampaikan ke publik tidak mempunyai manfaat/ tidak berguna bagi masyarakatnya, maka informasi tersebut akan menjadi sia-sia). Tom Wicker dalam New York Times mengungkapkan "kecenderungan wartawan untuk percaya pada sumber sama halnya dengan mewakili nama baik dari institusi tempat ia bekerja".

Edmund Lambeth dan John Merrill melihat sebagai komposisi penting dalam berita adalah etika media. Praktisi public relations juga harus dapat mempertimbangkan sejauh mana hubungannya dengan para klien, tanggung jawabnya terhadap pihak ketiga, prioritas kepada kepentingan publik. Dalam pendekatan ini Newson mengemukakan bahwa hasil individu atau personal dan kepentingan organisasi harus selaras dengan mindset seorang public relations. Praktik public relations masih muncul perbedaan mendasar antara public relations dan media. Perbedaan ini terjadi karena public relations dianggap representasi perusahaan dan media adalah representasi khalayak. Sebagai representasi perusahaan, tentu public relations berupaya meningkatkan citra positifdalam media. Sebagai representasi khalayak, media berupaya kritis terhadap informasi yang disampaikan public relations. Bagi seorang public relations, nilai berita ini penting sewaktu membuat pressrelease yang dikirim ke media. Semakin media menganggap berita yang disampaikan melalui press-release itu menarik (mempunyai nilai jual) maka semakin besar untuk dapat dimuat. Media berfungsi sebagai sarana penyebarluasan informasi tentang perusahaan kepada khalayak. Public relations harus memandang media sebagai mitra kerja yang saling mendukung, media adalah patner kerja public relations. Public relations bertanggung jawab menyampaikan dan menerima informasi dari khalayak sedangkan media bertanggung jawab menjalankan hak publik untuk memperoleh informasi. Adapun lima faktor yang mempengaruhi kebijakan redaksi dalam menentukan isi media, yakni :

\section{a. Faktor Individual}

Faktor ini berhubungan dengan latar belakang profesional dari pengelola media. Level individual melihat bagaimana pengaruh aspek-aspek personal dari pengelola media mempengaruhi pemberitaan yang akan ditampilkan kepada khalayak. Latar belakang individu seperti jenis kelamin, umur, atau agama, dan sedikit banyak mempengaruhi apa yang ditampilkan media. Latar belakang pendidikan, atau kecenderungan orientasi pada partai politik sedikit banyak bisa mempengaruhi profesionalisme dalam pemberitaan media.

\section{b. Rutinitas Media}

Berhubungan dengan mekanisme dan proses penentuan berita. Setiap media umumnya mempunyai ukuran sendiri tentang apa yang disebut berita, apa ciri-ciri berita yang baik, atau apa kriteria kelayakan berita. Ukuran tersebut adalah rutinitas yang berlangsung tiap hari dan menjadi prosedur standar bagi pengelola media yang berada di dalamnya. Rutinitas media ini juga berhubungan dengan mekanisme bagaimana berita dibentuk. Ketika ada sebuah peristiwa penting yang harus diliput, bagaimana bentuk pendelegasian tugasnya, melalui proses dan tangan siapa saja tulisan sebelum sampai ke proses cetak, siapa penulisnya, siapa editornya, dan seterusnya.

\section{c. Organisasi}

Level organisasi berhubungan dengan 
struktur organisasi yang secara hipotetik mempengaruhi pemberitaan. Pengelola media dan wartawan bukan orang tunggal yang ada dalam organisasi berita, ia sebaliknya hanya bagian kecil dari organisasi media itu . Masing-masing komponen dalam organisasi media bisa jadi mempunyai kepentingan sendiri-sendiri. Di dalam organisasi media, misalnya, selain bagian redaksi ada juga bagian pemasaran, bagian iklan, bagian sirkulasi, bagian umum, dan seterusnya. Masing-masing bagian tersebut tidak selalu sejalan. Mereka mempunyai tujuan dan target masing-masing, sekaligus strategi yang berbeda untuk mewujudkan target tersebut. Bagian redaksi misalnya menginginkan agar berita tertentu yang disajikan, tetapi bagian sirkulasi menginginkan agar berita lain yang ditonjolkan karena terbukti dapat menaikkan penjualan. Setiap organisasi berita, selain mempunyai banyak elemen juga mempunyai tujuan dan filosofi organisasi sendiri, berbagai elemen tersebut mempengaruhi bagaimana seharusnya wartawan bersikap, dan bagaimana juga seharusnya peristiwa disajikan dalam berita.

\section{d. Ekstra media}

Level ini berhubungan dengan faktor lingkungan di luar media. Meskipun berada di luar organisasi media, hal-hal di luar organisasi media ini sedikit banyak dalam banyak kasus mempengaruhi pemberitaan media. Ada beberapa faktor yang termasuk dalam lingkungan di luar media :

- Sumber berita. Sumber berita di sini dipandang bukanlah sebagai pihak yang netral yang memberikan informasi apa adanya, ia juga mempunyai kepentingan untuk mempengaruhi media dengan berbagai alasan: memenangkan opini publik, atau memberi citra tertentu kepada khalayak, dan seterusnya. Sebagai pihak yang mempunyai kepentingan, sumber berita tentu memberlakukan politik pemberitaan. Ia akan memberikan informasi yang sekiranya baik bagi dirinya, dan mengembargo informasi yang tidak baik bagi dirinya. Kepentingan sumber berita ini sering kali tidak disadari oleh media.

- Sumber penghasilan media, berupa iklan, bisa juga berupa pelanggan/pembeli media. Media harus survive, dan untuk bertahan hidup kadangkala media harus berkompromi dengan sumber daya yang menghidupi mereka.
Misalnya media tertentu tidak memberitakan kasus tertentu yang berhubungan dengan pengiklan. Pihak pengiklan juga mempunyai strategi untuk memaksakan versinya pada media. Ia tentu saja ingin kepentingannya dipenuhi, itu dilakukan di antaranya dengan cara memaksa media mengembargo berita yang buruk bagi mereka. Pelanggan dalam banyak hal juga ikut mewarnai pemberitaan media. Tema tertentu yang menarik dan terbukti mendongkrak penjualan, akan terusmenerus diliput oleh media. Media tidak akan menyia-nyiakan momentum peristiwa yang disenangi oleh khalayak.

- Pihak eksternal seperti pemerintah dan lingkungan bisnis. Pengaruh ini sangat ditentukan oleh corak dari masing-masing lingkungan eksternal media (baca teori normatif komunikasi massa, dan teori makro). Dalam negara yang otoriter misalnya, pengaruh pemerintah menjadi faktor yang dominan dalam menentukan berita apa yang disajikan. Keadaan ini tentu saja berbeda di negara yang demokratis dan menganut liberalisme. Campur tangan negara praktis tidak ada, justru pengaruh yang besar terletak pada lingkungan pasar dan bisnis.

\section{e. Ideologi}

Diartikan sebagai kerangka berpikir atau kerangka referensi tertentu yang dipakai oleh individu untuk melihat realitas dan bagaimana mereka menghadapinya. Berbeda dengan elemen sebelumnya yang tampak konkret, level ideologi ini abstrak. Ia berhubungan dengan konsepsi atau posisi seseorang dalam menafsirkan realitas. Menurut Raymond William (dalam Eriyanto, 2001: 70) klasifikasi terhadap penggunaan ideologi terdapat tiga uraian, yakni :

- Sebuah sistem kepercayaan yang dimiliki oleh kelompok atau kelas tertentu. Definisi ini terutama dipakai oleh kalangan psikologi yang melihat ideologi sebagai seperangkat sikap yang dibentuk dan diorganisasikan dalam bentuk yang koheren. Sebagai misal, seseorang mungkin mempunyai seperangkat sikap tertentu mengenai demontrasi buruh. Ia percaya bahwa buruh yang berdemontrasi mengganggu kelangsungan produksi. Oleh karenanya, demontrasi tidak boleh ada, karena hanya akan menyusahkan orang lain, membuat keresahan, menggangu kemacetan lalulintas, dan membuat persahaan mengalami kerugian besar. Jika bisa 
memprediksikan sikap seseorang semacam itu, kita dapat mengatakan bahwa orang itu mempunyai ideologi kapitalis atau borjuis. Meskipun ideologi disini terlihat sebagai sikap seseorang, tetapi ideologi di sini tidak dipahami sebagai sesuatu yang ada dalam diri individu sendiri, melainkan diterima dari masyarakat.

- Sebuah sistem kepercayaan yang dibuat 'ide palsu atau kesadaran palsu' yang biasa dilawankan dengan pengetahuan ilmiah. Ideologi dalam pengertian ini adalah seperangkat kategori yang dibuat dan kesadaran palsu dimana kelompok yang berkuasa atau dominan menggunakannya untuk mendominasi kelompok lain. Karena kelompok yang dominan mengontrol kelompok lain dengan menggunakan perangkat ideologi yang disebarkan ke dalam masyarakat, akan membuat kelompok yang didominasi melihat hubungan itu nampak natural, dan diterima sebagai kebenaran. Di sini, ideologi disebarkan lewat berbagai instrumen dari pendidikan, politik sampai media massa.

- Proses umum produksi makna dan ide. Ideologi disini adalah istilah yang digunakan untuk menggambarkan produksi makna.

Sementara itu, Shoemaker dan Reese (1996: 184) menyebut beberapa faktor yang memengaruhi kebijakan redaksi dalam memproduksi berita:

1 Faktor individual, berhubungan dengan latar belakang profesional dari pengelola media.

2 Rutinitas media, berhubungan dengan mekanisme dan proses penentuan berita.

3 Level organisasi, berhubungan dengan struktur organisasi yang secara langsung maupun tidak langsung memengaruhi pemberitaan.

4. Level ekstramedia, berhubungan dengan lingkungan di luar media, antara lain: Pertama, sumber berita, yang di sini dipandang bukan sebagai pihak yang netral, tetapi juga memiliki kepentingan untuk memengaruhi media dengan berbagai alasan, misalnya memenangkan opini publik, memberi citra tertentu kepada khalayak, dan sebagainya. Kedua, sumber penghasilan media, berupa pemasang iklan, penanam modal, dan audiens sebagai konseumen. Media harus survive sehingga kadangkala harus berkompromi dengan pihak-pihak dan bermacam sumber daya yang menghidupi mereka.
5. Pihak eksternal, seperti pemerintah dan lingkungan bisnis.

6 Level ideologi, yang diartikan sebagai kerangka berpikir atau kerangka referensi individu pekerja media dalam menafsirkan realitas dan bagaimana mereka menghadapinya.

\section{Penutup}

\section{Simpulan}

Bagi seorang public relations, nilai berita ini penting sewaktu membuat pressrelease yang dikirim ke media. Semakin media menganggap berita yang disampaikan melalui press-release itu menarik (memiliki news values) maka semakin besar untuk dapat dimuat. Wartawan pun karena kompetisi ketat tentu akan selektif dalam membuat berita. Tentu ia ingin beritanya dibaca orang. Karena itu dipilih mana yang dapat menarik perhatian dan penting untuk khalayak. Nilai berita biasanya ada pada judul atau kepala berita (head-news). Ini adalah bagian yang pertama kali dibaca orang. Bagaikan etalase toko, jika orang tertarik maka besar kemungkinan orang tersebut untuk masuk ke dalam toko. Demikian berita. Jika judulnya merangsang minat maka orang akan tertarik untuk membaca keseluruhan berita.

Masyarakat memandang berita sebagai sebuah fakta di lapangan yang kemudian disajikan apa adanya oleh media. Hal ini menyebabkan masayarakat merasa terkejut saat menyaksikan apa yang ditayangkan di media ternyata tidak sama dengan apa yang mereka saksikan. Dengan kata lain, apa yang ditampilkan media sudah melalui berbagai proses sehingga hasilnya tidak utuh lagi seperti fakta. Memang, tidak semua fakta bisa ditampilkan utuh dalam berita, tapi paling tidak campur tangan atau rekayasanya tidak terlalu menyimpang dari kondisi yang sesungguhnya. Dengan demikian, masyarakat harus menyadari berbagai pengaruh yang dihadapi media dalam menyampaikan sebuah berita.Berita dalam media selalu memiliki ideologi dominan yang terbentuk melalui tanda tersebut, artinya jika kita gali lebih dalam, teks media membawa kepentingan- 
kepentingan yang lebih luas dan kompleks. Oleh karenanya, harus diakui bahwa apa yang dimuat media massa tidak terlepas dari berbagai kepentingan atau kekuatan yang dibelakangnya. Media juga sangat dipengaruhi oleh lingkungan sekitarnya, termasuk kecenderungan opini yang berkembang dan ideologi yang berkembang di masyarakat.

Keberadaaan media massa dalam menyajikan informasi cenderung memicu perubahan serta banyak membawa pengaruh pada penetapan pola hidup dan perilaku masyarakat. Beragam informasi yang disajikan dapat memberi pengaruh yang berwujud positif dan negatif. Secara perlahan-lahan namun efektif, media membentuk pandangan masyarakat terhadap bagaimana seseorang melihat pribadinya dan bagaimana seseorang seharusnya berhubungan dengan dunia seharihari. Pesan/informasi yang disampaikan oleh media bisa jadi mendukung masyarakat menjadi lebih baik, membuat masyarakat merasa senang akan diri mereka, merasa cukup atau sebaliknya mengempiskan kepercayaan dirinya atau merasa rendah dari yang lain.

Senada dengan itu, Fishman (dalam McQuail, 2011 : 78) melengkapi teori ini dengan mengatakan bahwa ada dua pendekatan bagaimana proses produksi berita dilihat. Pandangan pertama sering disebut sebagai pandangan seleksi berita (selectivity of news) yang melahirkan teori seperti gatekeeper. Intinya adalah proses seleksi, komunikator akan memilih mana yang penting dan mana yang tidak, mana yang ditekankan dan mana yang disamarkan, mana yang layak diberitakan mana yang tidak. Pandangan ini seolah menyatakan adanya realitas riil yang diseleksi wartawan untuk dibentuk dalam sebuah berita. Pendekatan kedua adalah pendekatan pembentukan berita (creation of news). Dalam pandangan ini peristiwa bukan diseleksi, melainkan dibentuk. Wartawanlah yang membentuk peristiwa: mana yang disebut berita dan mana yang tidak. Realitas bukan diseleksi melainkan dikreasi oleh wartawan. Wartawan aktif berinteraksi dengan realitas dan sedikit banyak menentukan bagaimana bentuk dan isi berita dihasilkan.

Media massa seperti surat kabar, majalah, televisi dan radio, sering dijadikan objek studi, karena memang dipandang sebagai suatu institusi penting dalam masyarakat. Maka dari itu penulis menyadari betul bahwa media harus kembali pada aturan yang bisa menopang hajat hidup masyarakat banyak yakni "Tanah, air, udara kekayaan adalah milik Negara.." dikutip dari Undang-Undang Dasar (UUD) 1945 Pasal 33 ayat 3. Rekomendasi penulis sebagai berikut :

a. Media harus menjadi industri yang berubah dan berkembang, yang menciptakan lapangan kerja, barang dan jasa, serta menghidupkan industri lain yang terkait. Media juga merupakan industri tersendiri yang memiliki peraturan dan normanorma yang menghubungkan institusi tersebut dengan masyarakat dan institusi sosial lainnya

b. Media massa tidak boleh dijadikan sumber kekuatan, alat kontrol, manajemen, dan inovasi dalam masyarakat, yang dapat didayagunakan sebagai pengganti kekuatan atau sumber daya lainnya

c. Media harus menjadi wadah yang menampilkan peristiwa-peristiwa kehidupan masyarakat, baik yang bersifat nasional maupun internasional

d. Media harus bisa menyaring informasi yang berperan dalam mengembangkan kebudayaan, juga tata cara, mode, gaya hidup dan norma-norma yang tidak baik untuk budaya dan masyarakat Indonesia

e. Jangan jadikan media menjadi sumber dominan atau sumber primer, bukan saja bagi individu untuk memperoleh gambaran dan citra realitas sosial, tetapi juga bagi masyarakat dan kelompok secara kolektif. Karena media kerap menyuguhkan nilai-nilai dan penilaian normatif yang dibaurkan dengan berita dan hiburan. 


\section{Daftar Pustaka}

Eriyanto, (2001). Analisis Wacana. Pengantar Analisis Teks Media. Yogyakarta : LkiS

Kent, M. L., \& Taylor, M. (2002). Toward a Dialogic Theory of Public Relations. Public Relations Review.

Kovach, Bill dan Tom Rosenstiel. (2004). Sembilan Elemen Jurnalisme. Jakarta: Pantau.

Kriyantono, Rahmat. (2007), Pemberdayaan Konsumen Televisi melalui Ketrampilan Media Literacy dan Penegakan Regulasi Penyiaran. Surabaya : Jurnal Kommti BPPI V 10
Kriyantono, Rahmat. (2012). Public Relations Writing: Proses Produksi Media PR dan Publisitas Media, Edisi 2. Jakarta: Prenada Media Group.

McQuail, Denis. (2011). Teori Komunikasi Massa McQuail. Buku 2. Ed. 6. Jakarta : Salemba Humanika

Mencher, Melvin. (2000). News Reporting and Writing. New York: Mc. Graw.

Shoemaker \& Reese. (1996). Mediating the Message. Theories of Influences on Mass Media Content. USA : Longman.

(diakses di http://www.sciencedirect. com/sciencelarticle/piil S036381119980143X. pada tanggal 25 September 2015) 